\title{
STRUCTURAL CHANGES OF ECONOMIES: LITHUANIA IN THE GLOBAL CONTEXT ${ }^{1}$
}

\author{
Gitana DUDZEVIČIŪTE் ${ }^{a, b}$, Alminas MAČIULIS ${ }^{c}$, Manuela TVARONAVIČIENÉa, \\ ${ }^{a}$ The General Jonas Žemaitis Military Academy of Lithuania, Šilo g. 5A, 10322 Vilnius, Lithuania \\ ${ }^{\mathrm{b} V i l n i u s ~ G e d i m i n a s ~ T e c h n i c a l ~ U n i v e r s i t y, ~ S a u l e t e k i o ~ a l . ~ 11, ~} 10223$ Vilnius, Lithuania \\ 'Government of the Republic of Lithuania, Gedimino al. 11, 01103 Vilnius, Lithuania
}

Received 12 July 2013; accepted 02 January 2014

\begin{abstract}
Structural economic change theory focuses on the process through which economic structures have been transformed from traditional agriculture economy to more modern and industrially diverse manufacturing and service ones. The purpose of this paper is to detect the pattern of structural changes of the Lithuanian economy and to evaluate it in the global context. Structural economic statistics of the countries provide a view of a particular year delivered by indicator of the level of output in a considered sector of selected country's economy. Research methodology is based on the classic three-sector model, which involves structural changes' assessment methods and comparative analysis of statistical data on economic structures. The main findings reveal peculiarities of the structural change tendencies of the Lithuanian economy in the global context. First of all, the economies of selected countries are being analyzed from the point of view of three- sectoral divisions, such as agriculture, industry and services; the authors highlight the main tendencies of global economy taken by regions. After further in-depth analysis of the Lithuanian economic structural changes' assessment in the context of the other countries (regions) has been carried out and new evidence on patterns of structural change has been provided, concluding remarks have been formulated. Authors provide insights about peculiarities of Lithuanian economy's structural changes, which could potentially lead to respective policy implications, ultimately aiming acceleration of economic development.
\end{abstract}

Keywords: economy, change, industry, sector.

Reference to this paper should be made as follows: Dudzevičiūtè, G.; Mačiulis, A.; Tvaronavičienė, M. 2014. Structural changes of economies: Lithuania in the global context, Technological and Economic Development of Economy 20(2): 353-370.

JEL Classification: L16, L6, O13, O14.

1 Research prepared within framework of Long-term Economic Research Program, topic "Energetically secure and sustainable restructuring of Lithuanian industry sectors in the context of world economy development tendencies" confirmed by Research Council of Lithuania, (IEP-01/2012).

Corresponding author Gitana Dudzevičiūte

E-mail: gitana.dudzeviciute@vgtu.lt 


\section{Introduction}

Economic theory has given significant attention to structural change. Theoretical elaborations of structural transformation by Nobel laureate W. Arthur Lewis later in the mid-1950s were modified by John Fei and Guatav Ranis (Todaro, Smith 2009: 115). Attention to sectorial changes does not diminish in contemporary economic literature. Latest strand of scientific literature on economic development is devoted to interrelation of structural changes within economies of countries and their capacity to enhance their economic growth (Borseková et al. 2012; Lankauskienė, Tvaronavičienė 2012; Dudzevičiūtè 2013; Karnitis 2011; Tvaronavičienė, Lankauskienè 2013; Balkytė, Tvaronavičienè 2010; Vosylius et al. 2013; Miškinis et al. 2013). The term "structural change" has become widely used in economic research with variety of meanings and interpretations (Dudzevičiūtè 2013; Vosylius et al. 2013; Miškinis et al. 2013). In economic development, structural change is commonly understood as the different arrangements of productive activity in the economy and different distributions of productive factors among various sectors (Memedovic, Iapadre 2010; Dudzevičiūtè 2013; Vosylius et al. 2013). The most common meaning refers to long-term and persistent shifts in the sectoral composition of economic systems (Syrquin 2007; Memedovic, Iapadre 2010; Dudzevičiūtè 2013). Moreover, structural change is associated with the importance of different economic sectors over time (Karnitis 2011, Smaliukienè et al. 2012; Miškinis et al. 2013) measured by their share of output or employment. Sectoral changes support economic development and allow adjustment with the requirements of globalization processes (Smaliukiene et al. 2012; Tvaronavičienè et al. 2013; Karnitis 2011; Vosylius et al. 2013). Despite plethora of approaches towards understanding of structural changes in country's economy (e.g. Dudzevičiūtè 2013; Lankauskienè, Tvaronavičienè 2012; Vosylius et al. 2013) in the article we admit that "structural change can be a narrow definition limited to a change in input-output structure of production, or it can encompass a broader definition of a change in the industry composition of total production or final demand" (Kamaruddin, Masron 2010: 101).

The paper aims to overview and assess the Lithuanian economy's structural changes in the global context. The analysis bases on United Nations (UN) Statistics data (United Nations database 2013).

The paper is organized as follows. Section 1 gives a short summary of the relevant empirical literature on structural changes and research methodology. The studies of different researchers are summarized and the main research aspects are highlighted. Section 2 describes the main structural changes and their tendencies in Lithuania and in global economy as well; focuses on the structural shifts assessment, applying the absolute structural changes rate and the intensity coefficient of structural changes. The final section concludes summarizing of the main trends observed.

\section{Theories and patterns of structural changes}

\subsection{Empirical studies' review}

In scientific studies, sector changes have been analyzed from different angles and using several methodological approaches (Havlik 2004, 2007; Burda 2006; Bachmann, Burda 2008; 
Tvaronavičienė, Kalašinskaitė 2010; Karnitis 2011; Travkina, Tvaronavičienė 2011; Smaliukienė et al. 2012; Dudzevičiūtè 2012, 2013; Tvaronavičienè et al. 2013; Miškinis et al. 2013; Vosylius et al. 2013; Lankauskienė, Tvaronavičienè 2011; Borseková et al. 2012; Korsakiené, Baranauskienè 2011; Dudzevičiūtè, Tvaronavičienè 2011).

The overview of recent researches shows that some of the authors analyze structural changes in the economies of different countries in the context of a three main sectors such as agriculture, industry and services (Teigeiro, Solis 2007; Albu 2010; Gil' Mundinov 2011; Jiang 2011; Jorgenson, Timmer 2011; Mao, Yao 2012); others do researches in-depth of particular sector by commodities or types of services (Tanuwidjaja, Thangavelu 2007; Sharma, S., Sharma, J. 2007; Matsuyama 2009; Thomas et al. 2009; Kamaruddin, Masron 2010; Woodall et al. 2011; Noland et al. 2012; Vosylius et al. 2013).

Gil' Mundinov (2011) has analyzed changes in the sector structure of the Russian economy in the period of 1991-2009. The paper aims to determine the role ofstructural changes of internal factors. The analysis makes it possible to distinguish three basic factors that affect the sector structure of the Russian economy: the exchange rate, the interest rate and wages.

Jiang (2011) in the paper has empirically investigated the patterns, causes and implications of China's structural change and its contributions to regional growth. The author reveals that a Chinese region will generally rely on the structural change for its overall labor productivity growth more and more as the regional economy progresses. However, it tends to become harder for the region to take an advantage of structural change when achieving regional labor productivity growth. According to the author, the results of research have significant implications. The author has concluded, if structural change promotes regional labor productivity and at the same time interregional income, then it is important that this dual effect would be properly measured.

Mao and Yao (2012) have developed a dynamic general equilibrium model and studies structural change in a small open economy, South Korea, with two tradable sectors such as agriculture and manufacturing, and non-tradable sector, services. The authors have revealed falling employment share of agriculture and a rising share of services. Two countervailing effects have been identified: the productivity effect and the Balassa-Samuelson effect. According to the authors, the first effect has arisen from differential rates of productivity growth among sectors and has increased the share of manufacturing; the second one has enhanced the service sector and eventually has drawn labor from the manufacturing sector. The authors have calibrated the model and have found that the calibration fits the country's historical path of structural change.

Jorgenson and Timmer (2011) have concluded that "the classical trichotomy among agriculture, manufacturing, and services has lost most of its relevance" (26 p.). According to authors, services now contribute for about three-quarters to total value added and productivity growth in services predominate over productivity growth in goods production in Japan and the US, although not in Europe.

Kamaruddin and Masron (2010) have examined the structural changes and the sources of growth in the manufacturing sector in Malaysia. As the results have showed, most of the industries were non-resource based such as textiles, electrical and electronic products. The research has revealed that export is an increasingly important factor of change in the industrial 
growth patterns for the Malaysian economy. The authors have concluded that the structural changes in Malaysian economy are mainly caused by the reorientation of industrialization strategies as well as by variations in the composition of domestic demand.

Matsuyama (2009) has presented "a simple model of the world economy, in which productivity gains in manufacturing are responsible for the global trend of manufacturing decline, and yet, in a cross-section of countries, faster productivity gains in manufacturing do not necessarily imply faster declines in manufacturing" (478 p.).

Tanuwidjaja and Thangavelu (2007) in their paper have analyzed the relationship between structural changes and productivity of the manufacturing sector in the Japanese economy. The authors have decomposed the total labor productivity growth in Japan into labor productivity growth and structural change across in the manufacturing sector and have assessed the interaction between them. The manufacturing industries have been classified into four sectors according to the technological degree. The paper has revealed that the productivity is most notably in the medium-high-technology sector and this is a result of structural change occurred in the late 1990s.

The researchers have analyzed the services sector development in Asia and have assessed its potential for economic growth (Noland et al. 2012). The survey has indicated that services are an important source of output, growth and jobs, "however, its productivity greatly lags that of the advanced economies, which implies ample room for further growth" (12 p.). The study has concluded that the most important key challenge for all Asian countries is to improve the quality of services sector and to create more competitive services markets by removing a wide range of distortions.

According to Gawlikowska-Hueckel and Uminski (2008), structural change of economy is a result of the process of the adjustment of the national economy to a changing global market. These adjustments are related to the international specialization and competitiveness.

An overview of theoretical and empirical studies has showed that the analysis of economic structure and its dynamics is a research topic that continuously attracts researchers from different countries. The structural changes of economy can be analyzed on the basis of a wide range of indicators such as income-elasticity, productivity growth, employment concentration, share of output in GDP, contribution to total value added, total spending cross-sectors and others. Most of the studies have described the long-run evolution of economies from agricultural to industrial and then to service-based economic structure.

\subsection{Research methodology}

The analysis of economic structure started already in the first half of the 20th century and is associated with Fisher (1935), Clark (1940) and Fourastié (1954) works (GawlikowskaHueckel, Uminski 2008). They summarized the structural changes of the economy by using three-sector hypothesis that describes the long-run development of economies from agricultural to industrial and then to service-based economic structure.

The primary sector involves agriculture, forestry, hunting and fishing. It is based on the direct utilisation of natural resources. This sector is characterized by the law of diminish- 
ing returns. The secondary sector encompasses manufacturing. It is characterised by a big scale of production, which implies that considerable amount of capital is needed and that production process has to be efficiently organised. The tertiary sector involves services, where employment increases as economies grow. Workforce transfers from one sector to another are caused by changes in real income per capita as well as by changes in the demand structure (Gawlikowska-Hueckel, Uminski 2008; Clark 1957). The division of the economy into three sectors is the result of the technological progress. The primary economic sector is characterised by moderate technological progress, the secondary by fast, while the tertiary by slow. The author concluded, that an increase in the offer of the tertiary sector can happen almost only through a growth in employment.

Later, structural change theories were developed by Lewis (1954), Myint (1958), Todaro (1969), Ishikawa (1987), Syrquin (1988). Lewis' dual sector theory (1954) was based on the assumption that many developing countries had dual economies with both a traditional agricultural sector and a modern industrial sector. The traditional agricultural sector was characterized by low productivity, low income and savings and significant underemployment. The industrial sector was defined as technologically advanced with high levels of investment operating in an urban environment. Syrquin (1988) identified three stages of structural transformation in the evolution of economies: the first stage focuses on primary production; the second stage focuses on shifts towards the manufacturing sector, and during the third stage the share of service sector increases along with exports (Thakur 2008).

The research was guided by three-sector model provided in the works of Fisher (1935), Clark (1940), Fourastié (1954) and Gawlikowska-Hueckel, Uminski (2008). The comparative statistical analysis of the regions and countries was based on the economic logic of the primary-secondary-tertiary sector. The author refers to Syrquin's and Chenery's (1989) approach when structural change is studied in the process of economic growth. This allows to identify statistically certain change in economic structure using regional and the Lithuanian cross-sectoral data.

In order to evaluate sectoral shifts, the author uses structural changes assessment methods, such as the the absolute structural changes rate and the intensity rate of structural change, which are provided in the works of Domingo, Tonella (2000), Cortuk, Singh (2010), Memedovic, Iapadre (2010), Vitas (2012).

The absolute structural changes rate shows economic structural change and its impact on economic growth. Positive rate value means that structural change accelerates economic growth; and negative rate diminishes economic growth. The absolute structural changes rate is calculated as follows:

$$
\begin{aligned}
& M=D_{i}-D_{0} ; \\
& M_{\text {sum }}=\sum_{i=1}^{n} M_{i},
\end{aligned}
$$

where: $M$ - the absolute structural change rate; $D_{i}$ - economic activity share, $\% ; D_{0}$ - economic activity share, $\%$ in the basic year; $M_{\text {sum }}$ - sum of the absolute structural change rate. 
The intensity coefficient of structural changes shows the economic changes intensity in time $t_{i}$, compared with basic period. The bigger is the coefficient value, the more intensive structural changes of economy are going, and conversely. The intensity coefficient of structural changes is calculated as follows:

$$
K=\frac{\sqrt{\sum_{t=2}^{n}\left(S_{t i}-S_{t 0}\right)^{2}}}{m},
$$

where: $K$ - the intensity rate of structural changes; $S_{t i}$ - economic activity share; $t i$, to - current and basic time; $n$ - economic activity quantity; $m$ - year.

The main advantages of these indicators could be named as follows: they are easy to calculate, they are informative for interpretation of their impact on economic development. However, they give only general information and do not reveal the reasons for structural changes.

\section{Lithuanian structural changes in the global context}

\subsection{Movement to service based economy}

The investigations of structural changes started in the first half of the 20th century. "Threesector hypothesis" has described the long-run evolution of economies from agricultural to industrial and then to service-based economic structure defined as the process of tertiarization (Bachman, Burda 2008).

In terms of value added at current prices, the service sector was already dominant in 1970, making $52 \%$ of world production and $66 \%$ in 2011 (Fig. 1).
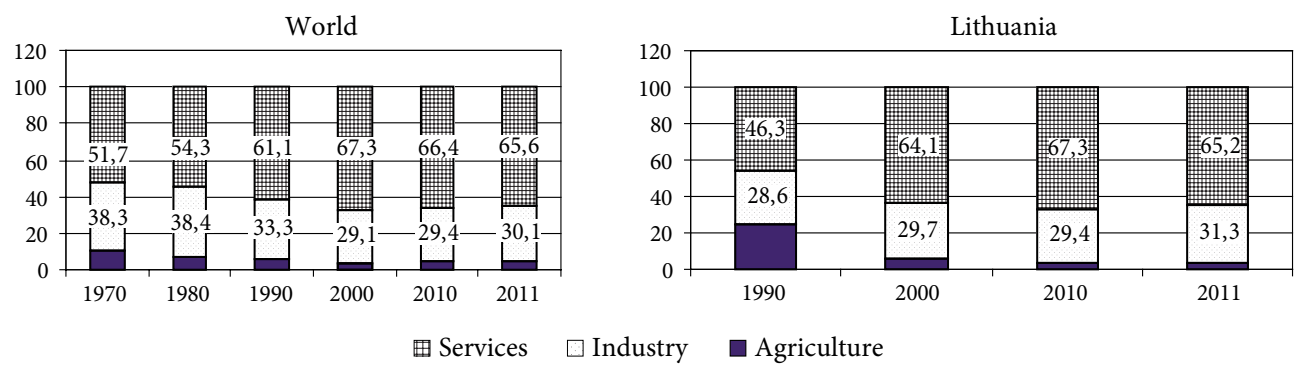

Fig. 1. Sector distribution of total value added in the World and Lithuania, in percent Source: authors' calculations based on the UN Statistics data.

Industry made 38\% in 1970 and 30\% in 2011, agriculture was $10 \%$ and $4 \%$ respectively. The most recent trends had not entirely correspond to the previous period. In a period of 2000-2011 the growth of world value added has been slower in the service sector than in agriculture and industry. This change can partly be explained by the recent increases in the relative prices of agricultural and mineral products, which have sustained their share of world value added (Memedovic, Iapadre 2010).

Lithuania, as independent country, has the short-run sector evolution. The main structural changes in a period of 1990-2011 support the view that tertiarization was the dominant 
feature of structural change in Lithuania as in global economy as well. The service sector was dominant in 1990, making $46 \%$ of the production and $65 \%$ in 2011 . The respective shares of industry was $29 \%$ in 1990 and $31 \%$ in 2011 , and those of agriculture made from $25 \%$ to $4 \%$. An unabated development of the Lithuanian service sector is visible until 2000, mainly because of the detriment of agriculture.

In a period of 2000-2011, the share of service sector has increased by 1.1 percentage points in Lithuania and the industry has grown nearly by 1.6 percentage points. Since 2000 , the structure of Lithuanian economy was close to the world economic structure and it leads to the conclusion that the Lithuanian economy has been integrated and significantly impacted by the developments in the world economy.

According to the United Nations statistics data, the Asian and the European economies are dominant in the world. The Asian agriculture sector produced more than $50 \%$ of world value added at current prices in 2011, the European share made about 20\%. Manufacturing produced about $40 \%$ of world value added in Asia and 30\% in Europe; service sector created about $25 \%$ and $35 \%$ of world value added respectively.

In Fig. 2 the main tendencies are shown of sector distribution of total value added by region.
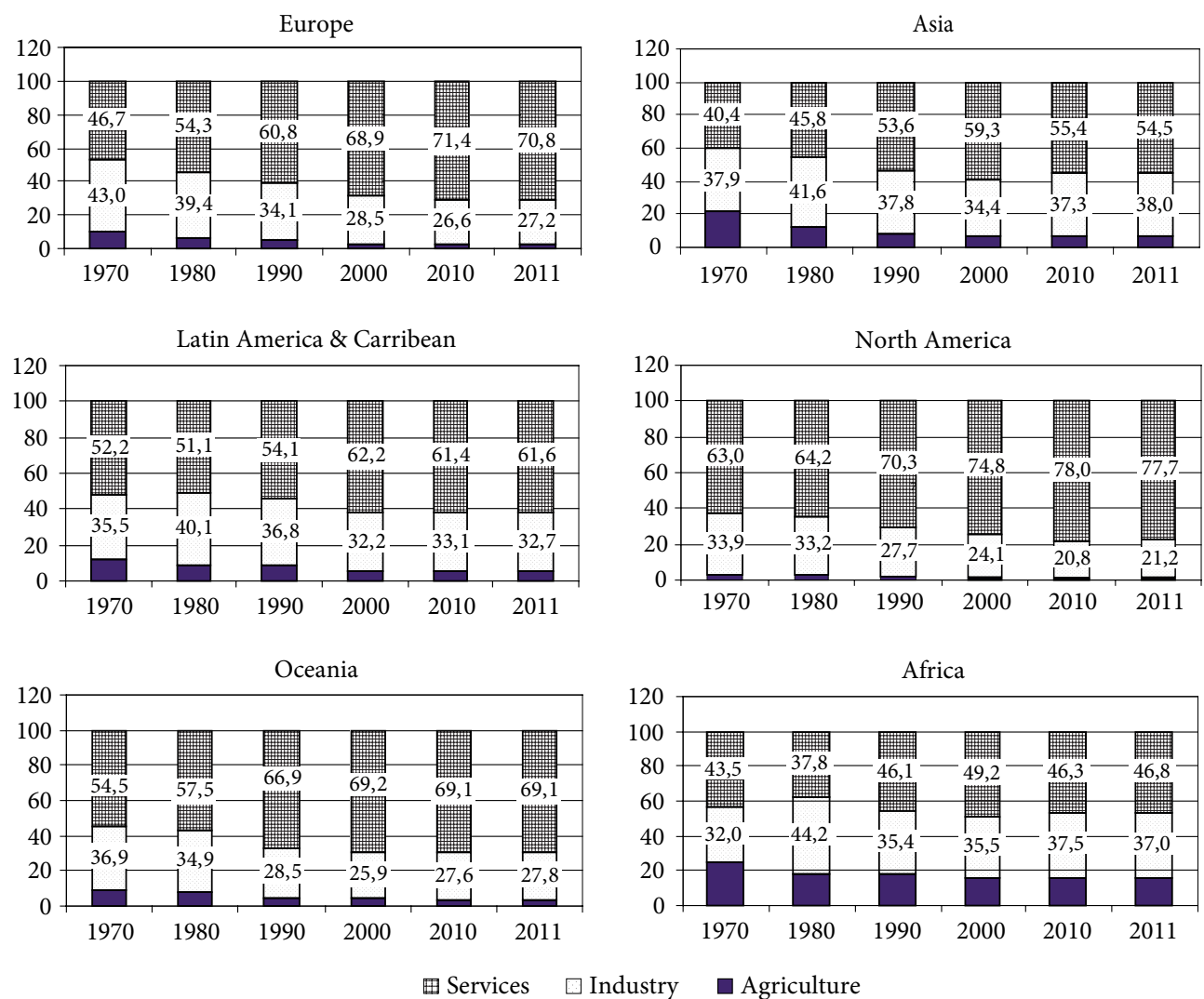

Fig. 2. Sector distribution of total value added by region, in percent Source: authors' calculations based on the UN Statistics data. 
Taking into account structural transformation patterns in different regions of the world economy between 1970 and 2011, the tendencies may be summarized as follows:

- The development of the service sector was impacted mainly by the detriment of agriculture. It happened in Asia, Latin America and the Caribbean. The same shifts happened in Lithuania as well;

- The development of the service sector was influenced by the detriment of industry mainly. It happened in Europe, North America and Oceania;

- The African shifts of service sector were impacted by agriculture as well as by industry. The economy of this region is characterized by a fairly strong specialization in agriculture.

- In the period of 2000-2011, tertiarization process slightly receded in Europe. The African and Asian service sector kept decreasing in the same period of time. Africa and Asia reported the most significant decrease of service sector by 2.4 and 4.8 percentage points respectively. Only in North America a process of tertiarization is visible from 1970 to 2011.

- In 2011, service sector took the biggest part in North America (78\%), Europe (71\%) and Oceania (69\%).

The structural changes' intensity by regions is summarized in Table 1.

Table 1. Intensity coefficient of the structural changes by regions

\begin{tabular}{lc}
\hline \multicolumn{1}{c}{ Country/region } & $\begin{array}{c}\text { Intensity coefficient of the structural } \\
\text { changes in } 1990-2011\end{array}$ \\
\hline Lithuania & 2.0 \\
\hline World & 0.6 \\
\hline Europe & 0.9 \\
\hline Asia & 0.2 \\
\hline Africa & 0.5 \\
\hline Latin America and the Caribbean & 0.6 \\
\hline North America & 0.6 \\
\hline Oceania & 0.2 \\
\hline
\end{tabular}

Source: authors' calculations based on the UN Statistics data.

Having evaluated structural economic changes in 1990-2011 by applying intensity coefficient, it can be stated that the Lithuanian structural changes' intensity was the highest all over the world in 1990-2011. It shows that the Lithuanian economic pattern just was in the process of its formation after the collapse of the Soviet Union and it is sensitive to external and internal factors as well.

A more detailed analysis is needed to explain structural shifts of the global economy. Next part presents in-depth analysis of the industry and service sector distribution of total value added. 


\subsection{Industry and service sectors distribution: structural analysis}

In part 2, three-sectors structural analysis showed the decrease of agricultural sector in all regions between 1970 and 2011 and in Lithuania between 1990 and 2011 as well. In some regions industry sector share of total value added decreased (Europe, Latin America and the Caribbean, North America and Oceania), other regions (Asia and Africa) reported growth of industry share if 1970 to compare wuth 2011 (Fig. 2). The share of industry sector increased in Lithuania between 1990 and 2011 (Fig. 3).

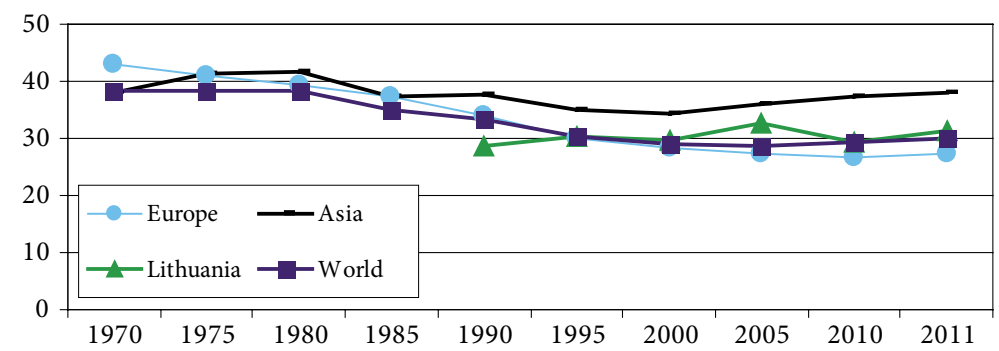

Fig. 3. Industry distribution of total value added by regions Source: authors' calculations based on the UN Statistics data.

Lithuanian industry sector's share kept increasing over a period of 1990-2011. It is different from the tendencies in Europe and in the World, where industry's share decreased. In 2011, the Asian economy reported the share of industry relatively higher than the Lithuanian, European and World average (Fig. 3), however Lithuania has industry with higher share of total value added than Europe and World average.

To understand the changes better, a more detailed structural analysis of the industry sector structure of total value added is presented in Table 2, Table 3 and Table 4.

Table 2. Mining and utilities share of total value added, in percent

\begin{tabular}{lccccccc}
\hline \multicolumn{1}{c}{ Regions } & 1970 & 1980 & 1990 & 2000 & 2011 & $\begin{array}{c}\text { Absolute rate of } \\
\text { structural changes } \\
\text { in 1970-2011, } \\
\text { percentage points }\end{array}$ & $\begin{array}{c}\text { Absolute rate of } \\
\text { structural changes } \\
\text { in 2000-2011, } \\
\text { percentage points }\end{array}$ \\
\hline Europe & 2.5 & 3.5 & 4.3 & 3.6 & 5.4 & 2.9 & 1.8 \\
\hline Asia & 4.8 & 10.6 & 4.9 & 4.8 & 9.2 & 4.4 & 4.4 \\
\hline $\begin{array}{l}\text { Latin America } \\
\text { \& Carribean }\end{array}$ & 5.9 & 8.0 & 7.5 & 7.2 & 10.0 & 4.1 & 2.8 \\
\hline North America & 4.5 & 7.3 & 5.1 & 3.6 & 4.4 & -0.1 & 0.8 \\
\hline Oceania & 6.6 & 9.8 & 8.8 & 7.8 & 10.8 & 4.2 & 3.0 \\
\hline Africa & 11.7 & 23.9 & 15.2 & 18.4 & 22.0 & 10.3 & 2.9 \\
\hline World & 4.0 & 7.1 & 5.2 & 4.5 & 7.4 & 3.4 & -0.7 \\
\hline Lithuania & N/A & N/A & 2.8 & 4.8 & 4.1 & $1.3 *$ & \\
\hline$*$ The change in 1990-2011. & & & & & \\
Source: authors' calculations based on the UN Statistics data. &
\end{tabular}


Table 3. Manufacturing share of total value added, in percent

\begin{tabular}{lccccccc}
\hline \multicolumn{1}{c}{ Regions } & 1970 & 1980 & 1990 & 2000 & 2011 & $\begin{array}{c}\text { Absolute rate of } \\
\text { structural changes } \\
\text { in 1970-2011, } \\
\text { percentage points }\end{array}$ & $\begin{array}{c}\text { Absolute rate of } \\
\text { structural changes } \\
\text { in 2000-2011, } \\
\text { percentage points }\end{array}$ \\
\hline Europe & 32.4 & 28.5 & 13.0 & 19.3 & 15.6 & -16.8 & -3.7 \\
\hline Asia & 27.5 & 23.8 & 24.8 & 23.4 & 22.7 & -4.8 & -0.7 \\
\hline $\begin{array}{l}\text { Latin America } \\
\text { \& Carribean }\end{array}$ & 23.3 & 24.2 & 23.7 & 19.3 & 16.3 & -7.0 & -3.0 \\
\hline North America & 24.2 & 21.0 & 18.1 & 16.0 & 12.4 & -11.8 & -3.6 \\
\hline Oceania & 6.1 & 9.2 & 8.3 & 7.6 & 9.3 & 3.2 & 1.7 \\
\hline Africa & 15.2 & 14.8 & 15.4 & 12.8 & 9.6 & -5.6 & -3.2 \\
\hline World & 27.7 & 24.6 & 21.7 & 19.2 & 16.9 & -10.8 & -2.3 \\
\hline Lithuania & N/A & N/A & 16.5 & $\mathbf{1 8 . 8}$ & $\mathbf{2 0 . 6}$ & $4.1^{\star}$ & 1.8 \\
\hline
\end{tabular}

* The change in 1990-2011.

Source: authors' calculations based on the UN Statistics data.

On the basis of the industry sector's structure and its dynamics at global level, the main tendencies can be distinguished as follows:

- Mining and utilities dominate in industry sector with a significant share amounted to $20 \%$ of total value added in Africa. Over a period of 2000-2011, mining and utilities in Africa increased by more than 3 percentage points. It can be described by the decline of the service sectors' share in this region.

- In other regions (Europe, Asia, Latin America \& Caribbean, North America and Oceania) mining and utilities have made $4-11 \%$ of total value added. Lithuania belongs to this group of countries as well.

- Lithuanian mining and utilities share increased from 3\% in 1990 to 4\% in 2011. Lithuanian mining and utilities share of total value added was less than World and Europe average.

The overview of the manufacturing sector's dynamic at global level revealed the following aspects (Table 3):

- Manufacturing sector dominates in Europe, Asia, Latin America \& Caribbean and Lithuania making the share of total value added of 16-23\%. Over a period of 1970-2011, all regions reported decrease of manufacturing sector, except Oceania. This decrease was entirely offset by service sector development.

- In 2000-2011, the decrease of manufacturing sector was recorded also in all regions, except Oceania and Lithuania, where manufacturing growth was amounted to 2 percentage points.

- Lithuanian manufacturing sector made $21 \%$ of total value added in 2011 . It has increased by 4 percentage point from 1990.

Over a period of 1970-2011, construction sector's share made of 4-8\% of total value added (Table 4). In this period more notable structural changes happened in Europe, where the share of construction declined by 2 percentage points. Lithuanian construction sector's share decreased from $9 \%$ in 1990 to $7 \%$ in 2011. 
Table 4. Construction share of total value added, in percent

\begin{tabular}{lccccccc}
\hline Regions & 1970 & 1980 & 1990 & 2000 & 2011 & $\begin{array}{c}\text { Absolute rate of } \\
\text { structural changes } \\
\text { in 1970-2011, } \\
\text { percentage points }\end{array}$ & $\begin{array}{c}\text { Absolute rate of } \\
\text { structural changes } \\
\text { in 2000-2011, } \\
\text { percentage points }\end{array}$ \\
\hline Europe & 8.1 & 7.4 & 6.8 & 5.6 & 6.2 & -1.9 & 0.6 \\
\hline Asia & 5.7 & 7.2 & 8.0 & 6.3 & 6.2 & 0.5 & -0.1 \\
\hline $\begin{array}{l}\text { Latin America \& } \\
\text { Carribean }\end{array}$ & 6.3 & 7.9 & 5.7 & 5.8 & 6.5 & 0.2 & 0.7 \\
\hline North America & 5.2 & 4.9 & 4.6 & 4.5 & 4.4 & -0.8 & -0.1 \\
\hline Oceania & 8.3 & 7.4 & 6.2 & 5.3 & 7.7 & -0.6 & 2.4 \\
\hline Africa & 5.0 & 5.5 & 4.8 & 4.3 & 5.4 & 0.4 & 1.1 \\
\hline World & 6.5 & 6.7 & 6.3 & 6.4 & 5.8 & -0.7 & -0.6 \\
\hline Lithuania & N/A & N/A & $\mathbf{9 . 2}$ & $\mathbf{6 . 0}$ & $\mathbf{6 . 5}$ & $-2.7^{*}$ & $\mathbf{0 . 5}$ \\
\hline$*$ The chanc
\end{tabular}

* The change in 1990-2011.

Source: authors' calculations based on the UN Statistics data.

Service sector kept increasing in all regions during a period of 1970-2011. Lithuania has reported service sector's growth as well in 1990-2011 (Fig. 4, Table 5).

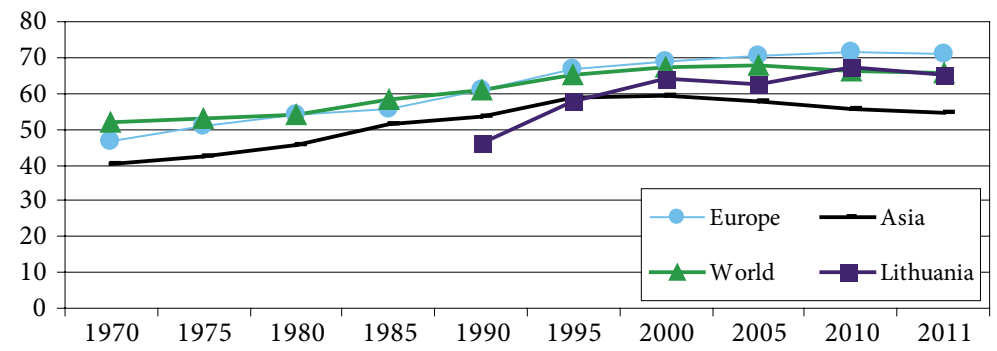

Fig. 4. Services' sector distribution of total value added by region, in percent Source: authors' calculations based on the UN Statistics data.

In 1990, Lithuania had the lower services' sector share of total value added than World, Europe and Asia average. It made $46 \%$ of total value added. During a period of five years Lithuanian services' sector growth rate was twice higher comparing to Europe, World and Asia average. In 1995 Lithuania reached Asian service sector level and exceeded it in 2000. In 2011 Lithuania with service sector share was very close to the World average; however it did not reach the Europe average. The structure of service sector by regions is shown in the Table 5.

Wholesale and retail trade, restaurants and hotels, transport, storage and communications made the biggest part in the service sector. These sub-sectors have produced over $20 \%$ of total value added. Between 1970 and 2011, Europe and North America reported greater structural shifts of wholesale and retail trade, restaurants and hotels. The contribution of this sub-sector to total European value added increased by 5 percentage points; the same indicator in North America decreased by more than 4 percentage points. Over a period of 1990-2011, the Lithuanian wholesale and retail trade, restaurants and hotels services' contribution to total value added rose until 2011 when it reached almost 20\%. In 1990-2011, the Lithuanian 
transport, service and communications' share increased by more than 7 percentage points and made 15\% in 2011. Lithuanian specialization is fairly strong in wholesale and retail trade and transport and communication. The shares of these sub-sectors were higher than World and Europe average.

Table 5. Service sector structure by regions of total value added, in percent

\begin{tabular}{clllllll}
\hline $\begin{array}{c}\text { Service sector } \\
\text { structure } \\
\text { by regions }\end{array}$ & 1970 & 1980 & 1990 & 2000 & 2011 & $\begin{array}{c}\text { Absolute rate of } \\
\text { structural changes } \\
\text { in 1970-2011, } \\
\text { percentage points }\end{array}$ & $\begin{array}{c}\text { Absolute rate of } \\
\text { structural changes } \\
\text { in 2000-2011, } \\
\text { percentage points }\end{array}$ \\
\hline
\end{tabular}

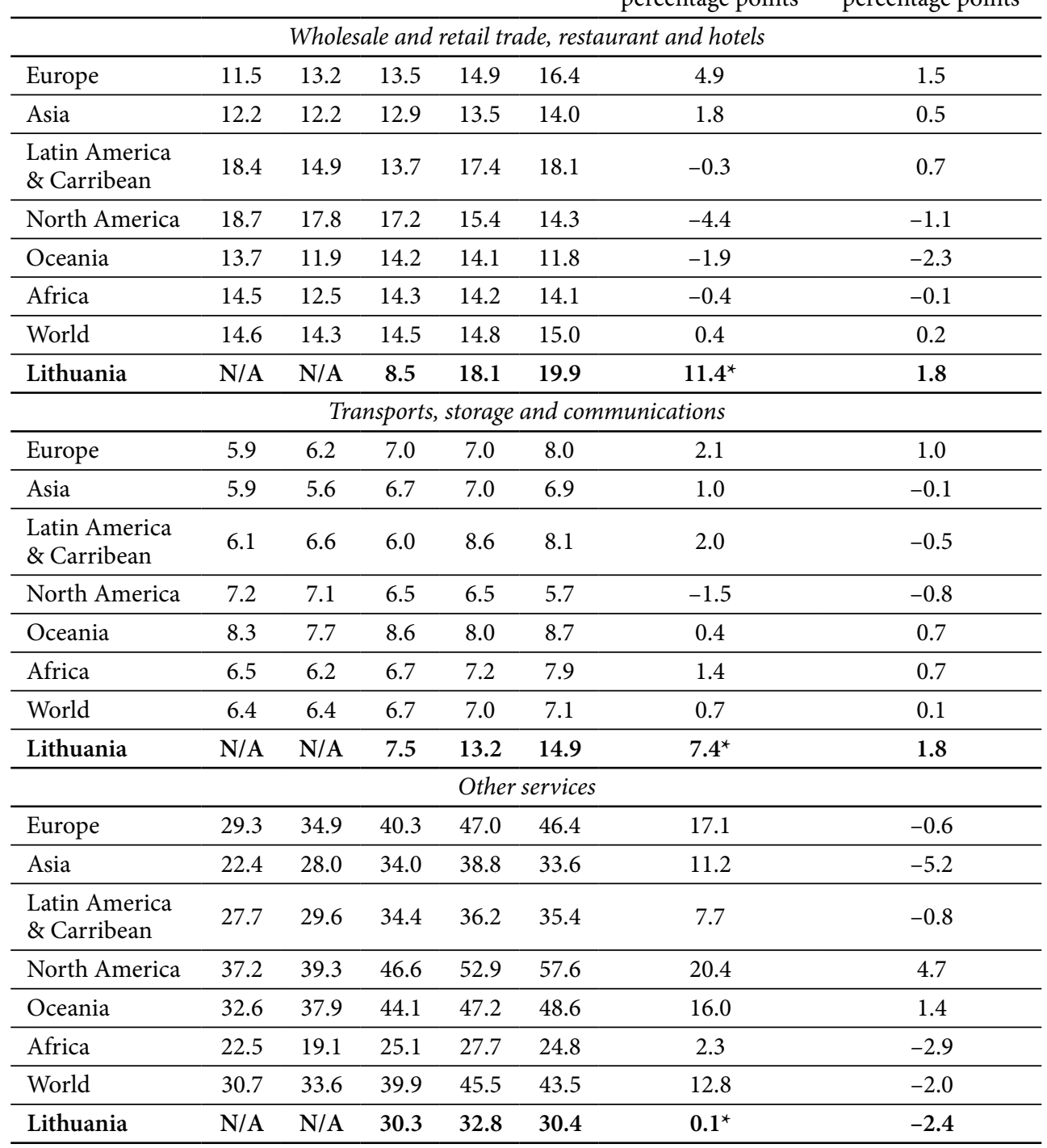

* The change in 1990-2011.

Source: authors' calculations based on theUN Statistics data. 
In 1990, Lithuania had the lower services' sector share of total value added than World, Europe and Asia average. It made $46 \%$ of total value added. During a period of five years Lithuanian services' sector growth rate was twice higher comparing to Europe, World and Asia average. In 1995 Lithuania reached Asian service sector level and exceeded it in 2000. In 2011 Lithuania with service sector share was very close to the World average; however it did not reach the Europe average. The structure of service sector by regions is shown in the Table 5 .

Wholesale and retail trade, restaurants and hotels, transport, storage and communications made the biggest part in the service sector. These sub-sectors have produced over $20 \%$ of total value added. Between 1970 and 2011, Europe and North America reported greater structural shifts of wholesale and retail trade, restaurants and hotels. The contribution of this sub-sector to total European value added increased by 5 percentage points; the same indicator in North America decreased by more than 4 percentage points. Over a period of 1990-2011, the Lithuanian wholesale and retail trade, restaurants and hotels services' contribution to total value added rose until 2011 when it reached almost 20\%. In 1990-2011, the Lithuanian transport, service and communications' share increased by more than 7 percentage points and made $15 \%$ in 2011. Lithuanian specialization is fairly strong in wholesale and retail trade and transport and communication. The shares of these sub-sectors were higher than World and Europe average.

Other services include the activities such as financial intermediation, real estate and business activities, public administration, education, and health and social work. In 1970-2011, the most important changes of other services happened in Europe, North America and Oceania, where the growth of other services in total value added was higher than the World average and made 16-20 percentage points. In Lithuania the share of other services has remained stable since 1990.

\subsection{Lithuania in the context of the Scandinavian countries}

In the previous sections the authors have described the Lithuanian sectoral shifts in the global context. In this one, the Lithuanian economy's structure has been overviewed in comparison with the average of the Scandinavian counties (Sweden, Denmark, Finland and Norway). The Scandinavian countries have been chosen due to their advanced economies and their successful development in the global context. The structural comparison has been based on the latest UN Statistics data for the period of 1990-2011.

In 1990, the share of the Lithuanian agriculture in total value added was more sizeable than in the Scandinavian countries (Fig. 5). In 1990, the Lithuanian industries share was very similar to the Scandinavian countries average. It made about $29 \%$ in total value added in Lithuania and $31 \%$ in the Scandinavian countries. From all industrial activities only construction had bigger share in total value added in Lithuania than in the Scandinavian countries. The most visible gap was between the Lithuanian service sector contribution to total value added and the Scandinavian countries. In 1990 it made $46 \%$ and 65\% respectively.

Over a period of twenty years, the significant fall in the Lithuanian agricultural activity was entirely offset by the development of the services' sector. The Lithuanian agricultural contribution to total value added decreased by more than 20 percentage points and made $3.5 \%$ in 2011, service sector increased by 19 percentage points and amounted to 65\% in 2011 (Fig. 5). 
1990

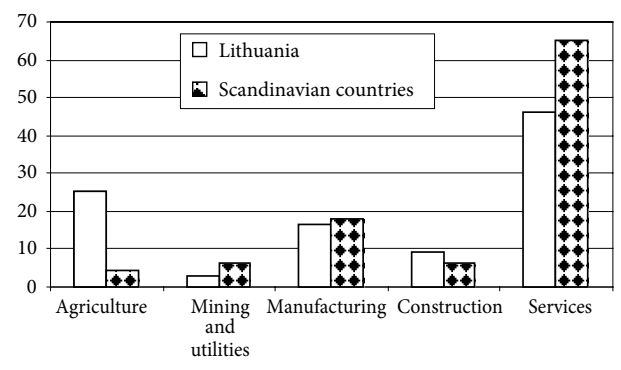

2011

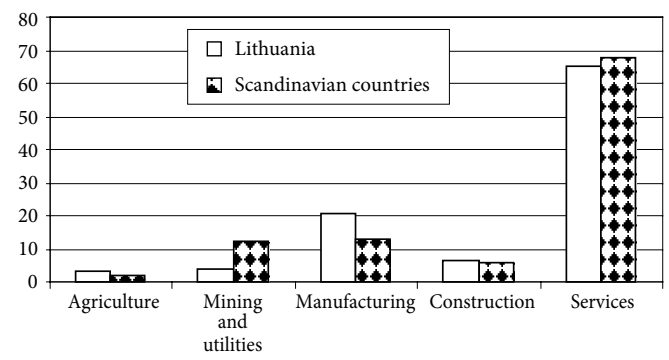

Fig. 5. The structures of the Lithuanian and the Scandinavian economies, in percent Source: authors' calculations based on the UN Statistics data.

In 2011, the Lithuanian economic structure can be characterized by greater contribution of agricultural and manufacturing activities to total value added and less share of mining and utilities and services' sector comparing with the average of the Scandinavian countries.

Structural changes of economy can have positive or negative effect to economic development. The authors evaluate structural changes impact on the Lithuanian economy as well as the Scandinavian countries, applying the absolute structural changes rate and the intensity coefficient of structural changes. The results are summarized in Table 6.

Table 6. The coefficients of structural changes

\begin{tabular}{lcccc}
\hline \multicolumn{1}{c}{ Country / sectors } & 1990 & 2011 & $\begin{array}{c}\text { Absolute rate of structural } \\
\text { changes, percentage points }\end{array}$ & $\begin{array}{c}\text { Intensity coefficient of } \\
\text { structural changes }\end{array}$ \\
\hline Agriculture & 25.1 & 3.5 & -21.6 & 1.0 \\
\hline Mining and utilities & 2.8 & 4.1 & 1.3 & 0.1 \\
\hline Manufacturing & 16.5 & 20.6 & 4.1 & 0.2 \\
\hline Construction & 9.2 & 6.5 & -2.7 & 0.1 \\
\hline Services & 46.3 & 65.2 & 18.9 & 0.9 \\
\hline Total & $\mathbf{1 0 0}$ & $\mathbf{1 0 0}$ & - & 2.3 \\
\hline & & Scandinavian countries & 0.1 \\
\hline Agriculture & 4.3 & 1.8 & -2.5 & 0.3 \\
\hline Mining and utilities & 6.2 & 12.1 & 5.9 & 0.2 \\
\hline Manufacturing & 18.1 & 12.9 & -5.2 & 0.0 \\
\hline Construction & 6.4 & 5.7 & -0.7 & 0.1 \\
\hline Services & 65 & 67.5 & 2.5 & $\mathbf{0 . 7}$ \\
\hline Total & $\mathbf{1 0 0}$ & $\mathbf{1 0 0}$ & - & \\
\hline
\end{tabular}

Source: authors' calculations based on the UN Statistics data.

Having evaluated structural changes of economies applying suggested methods and based on data over 1990-2011, it can be stated, that the economic growth was mainly negatively resulted by construction sector in Lithuania; and manufacturing as well as construction activities in the Scandinavian countries. Absolute rate of structural changes shows the decrease of 
agricultural sector in total value added in Lithuania and the Scandinavian countries as well. It could be treated as positive change in respect that its impact on social development has been considered as negative factor. Service sector development in Lithuania and the Scandinavian economies sustained economic growth. The intensity coefficient of the structural changes showed, that structural changes in the Lithuanian economy were significantly more intensive than in the Scandinavian countries. It means that the Lithuanian economic structure was more sensitive and was easily affected by external and internal factors over 1990-2011.

\section{Conclusions}

The research was guided by three- sector model provided in the works of Fisher (1935), Clark (1940), Fourastié (1954) and Gawlikowska-Hueckel, Uminski (2008). The comparative statistical analysis of the regions was based on the economic logic of the primary-secondary-tertiary sector. The assessment of the structural changes based on the absolute structural changes rate and the intensity coefficient of structural changes.

The research results mainly confirmed, that in the last decade agricultural as well as industrial sectors were growing more slowly; and the structure of the global economy has changed to service based economic structure.

In 1990, the Lithuanian economic structure was close to the African economic structure with relatively high agricultural sector contribution (more than 20\%) to total value added and relatively low share of service sector (about $46 \%$ ).

In 1990, the Lithuanian industry sector was at least developed comparing with the average of Asia, Europe and the World. It was close to the North American and Oceania average by the contribution to total value added. Over a period of 1990-1995, the Lithuanian industry sector contribution to total economy was growing, while it was decreasing in Europe, Asia and the World regions. At the same period of time, the process of tertiarization was apparent in global economy and the Lithuanian service sector growth was twice faster than the European and Asian countries average.

Over a period of 1990-2011, more intensive structural changes have occurred in Lithuania. It was assessed by structural changes intensity coefficient value, which was twice greater than in Europe, more than three times greater than in America and Africa; and ten times greater than in Asia and Oceania. It shows that the Lithuanian economic structure just was in the process of its formation after the collapse of the Soviet Union, when Lithuania became independent country; and it was sensitive to external and internal factors as well.

In 2000-2011, the Lithuanian economic structure was very close to the global economic structure, however, by the services sector's contribution to total value added, the Lithuanian economy was behind the European economy.

In 2011, the Lithuanian economic structure can be characterized by greater contribution of the agricultural and manufacturing activities to total value added and less share of services' sector comparing with the average of the Scandinavian countries.

Over a period of 1990-2011, the most significant structural changes, which negatively impacted on economic growth, have occurred in the Lithuanian construction sector, and manufacturing sector in the Scandinavian countries. Significant service sector development 
in Lithuania sustained economic growth. Mining and utilities sector changes had positive effect to the Scandinavian countries economic development. The structural changes of the Lithuanian economy were three times more intensive than in the Scandinavian countries in 1990-2011.

Observations provided above lead to general conclusion: provided evidences suggest that the Lithuanian sectorial shifts are leading to economy structure, which is rather typical for developed countries. On the other hand, the path of structural change suggests that observed Lithuania's structural shifts are more intensive than structural changes in other considered countries. That peculiarity leads to idea that economies of different countries can be characterized by different dynamic irrespective to their development level. It means that some countries are plausibly more sensitive to economic policies, others less sensitive. Lithuania in that context reveals it as country susceptible to economic conditions which could be restructured further by purposefully selected means of economic policy.

\section{References}

Albu, L.-L. 2010. Trends in structural changes and convergence in EU and in Adriatic-Balkans region, Studies in Business and Economics. $66 \mathrm{p}$.

Bachmann, R.; Burda, M. 2008. Sectoral transformation, turbulence and labor market dynamics in Germany, IZA Discussion Paper 3324.

Balkyte, A.; Tvaronavičienè, M. 2010. Perception of competitiveness in the context of sustainable development: facets of "Sustainable competitiveness", Journal of Business Economics and Management 11(2): 341-365. http://dx.doi.org/10.3846/jbem.2010.17

Borseková, K.; Petríková, K.; Vaňová, A. 2012. The methodology of use and building competitive advantage on the regional level, Journal of Security and Sustainability Issues 2(1): 41-50.

Burda, M. 2006. Factor reallocation in Eastern Germany after reunification, American Economic Review (96): 368-374.

Clark, C. 1940. The conditions of economic progress. London: Macmillan. $490 \mathrm{p}$.

Clark, C. 1957. The conditions of economic progress. London: Macmillan. $491 \mathrm{p}$.

Cortuk, O.; Singh, N. 2010. Structural changes and growth in India, Economics Letters 2: 178-181.

Domingo, C.; Tonella, G. 2000. Towards a theory of structural change, Structural Change and Economic Dynamics 11(1): 209-225.

Dudzevičiūtè, G. 2013. The research of the economic structural changes: energy consumption aspect, Journal of Security and Sustainability Issues 2(4): 13-23. http://dx.doi.org/10.9770/jssi.2013.2.4(2)

Dudzevičiūtè, G.; Tvaronavičienè, M. 2011. Measurement framework of innovation activity: theoretical approaches' analysis, Journal of Security and Sustainability Issues 1(1): 61-73.

http://dx.doi.org/10.9770/jssi.2011.1.1(6)

Dudzevičiūtè, G. 2012. Lithuanian security of energy supply and consumption in the context of the European Union countries, in International Scientific Conference "Whither Our Economies", 15-16 October, 2012, 32-38. ISSN (online) 2029-8501.

Fisher, A. 1935. The clash of progress and security. London: Macmillan. $25 \mathrm{p}$.

Gawlikowska-Hueckel, K.; Uminski, S. 2008. Structural changes in the economy of Polish regions, European Integration Studies (2): 88-97.

Gil' Mundinov, V. M. 2011. Analysis of structural changes in the Russian economy in conditions of intersectoral competition, Problems of Economic Transition 54(3): 44-53. 
Havlik, P. 2004. Structural change, productivity and employment in the New EU member states, EU DG Employment Research Project Papers, the Vienna Institute for International Economic Studies. $36 \mathrm{p}$.

Havlik, P. 2007. Economic restructuring in the new EU member states and selected newly independent states: the effects on growth, employment and productivity, The Vienna Institute for International Economic Studies (12): 10-45.

Ishikawa, S. 1987. Structural change, in Eatwell, J.; Milgate, M.; Newman, P. (Eds.). A Dictionary of Economics 4: 523-525.

Jiang, Y. 2011. Structural change and growth in China under economic reforms: patterns, causes and implications, Review of Urban \& Regional Development Studies 23(1): 48-65.

Jorgenson, D. W.; Timmer, M. P. 2011. Structural change in advanced nations: a new set of stylised facts, The Scandinavian Journal of Economics 113(1): 1-29.

Kamaruddin, R.; Masron, T. A. 2010. Sources of growth in the manufacturing sector in Malaysia: evidence from ARDL and structural decomposition analysis, Asian Academy of Management Journal 15(1): 99-116.

Karnitis, E. 2011. Strategy and efficient mechanisms to improve security and sustainability of the natural gas supply in Baltic States, Journal of Security and Sustainability Issues 1(1): 3-15.

http://dx.doi.org/10.9770/jssi.2011.1.1(1)

Korsakiene, R.: Baranauskienè, A. 2011. Factors impacting sustainable internationalization: a case of multinational company, Journal of Security and Sustainability Issues 1(1): 52-60. http://dx.doi.org/10.9770/jssi.2011.1.1(5)

Lankauskienè, T.; Tvaronavičienè, M. 2011. Interrelation of countries' development level and foreign direct investments performance, Journal of Business Economics and Management 12(3): 546-565. http://dx.doi.org/10.3846/16111699.2011.599412

Lankauskiené, T.; Tvaronavičienè, M. 2012. Security and sustainable development approaches and dimensions in the globalization context, Journal of Security and Sustainability Issues 1(4): 287-297.

Lewis, A. 1954. Economic development with unlimited supplies of labor, Manchester School 22: 139-191.

Mao, R.; Yao, Y. 2012. Structural change in small open economy: an application to South Korea, Pacific Economic Review 17(1): 29-56.

Matsuyama, K. 2009. Structural change in an interdependent world: a global view of manufacturing decline, Journal of the European Economic Association 7(2-3): 478-486.

Miškinis, V.; Baublys, J.; Lekavičius, V.; Morkvėnas, A. 2013. New changes in Lithuanian energy sector, Journal of Security and Sustainability Issues 2(3): 15-28. http://dx.doi.org/10.9770/jssi.2013.2.3(2)

Memedovic, O.; Iapadre, L. 2010. Structural change in the world economy: main features and trends", UNIDO, Working Paper (24): $62 \mathrm{p}$.

Myint, H. 1958. The classical theory of international trade and the underdeveloped countries, Economy 68(270): 317-337.

Noland, M.; Park, D.; Estrada, G. B. 2012. Developing the services sector as engine of growth for Asia: an overview, Peterson Institute for International Economics. $50 \mathrm{p}$.

Sharma, S.; Sharma, J. 2007. An empirical analysis of growth and structure of service sector in India, The Journal of Business Perspective 11(4): 45-52.

Smaliukienè, R.; Dudzevičiūte, G.; Adekola, A. F.; Aktan, B. 2012. The investigation of the Lithuanian growth and industry export dependence on energetic resources, Journal of Security and Sustainability Issues 2(2): 69-78.

Syrquin, M. 1988. Patterns of structural change, Handbook of Development Economics 1: 203-268.

Syrquin, M. 2007. Kuznets and Pasinetti on the study of structural transformation: never the Twain shall meet?, ICER, Working Paper (46): 67 p. 
Syrquin, M.; Chenery, H. B. 1989. Patterns of development: 1950 to 1983, World Bank Discussion Papers, No. 41. World Bank, Washington, DC.

Tanuwidjaja, E.; Thangavelu, S. 2007. Structural change and productivity growth in the Japanese manufacturing industry, Global Economic Review 36(4): 385-405.

Teigeiro, L. R.; Solis, J. S. 2007. Coefficient stability and structural change in the Spanish economy, Economic Change \& Restructuring (40): 387-409.

Thakur, S. K. 2008. Identification of temporal fundamental economic structure (FES) of India: an inputoutput and cross-entropy analysis, Structural Change and Economic Dynamics 19: 132-151.

Thomas, S.; Ryany, C.; Wong, J. W., et al. 2009. Coping with structural change in construction: experiences gained from advanced economies, Construction Management and Economics 27: 165-180.

Todaro, M. P. 1969. A model of labor migration and urban unemployment in less developed countries, American Economic Review 59(1): 138-149.

Todaro, M. P.; Smith, S. C. 2009. Economic development. $10^{\text {th }}$ edition. Addison-Wesley. 862 p. ISBN: 978-1-4058-7424-3.

Travkina, I.; Tvaronavičienė, M. 2011. Export competitiveness and domestic productivity facets: case of Lithuania, Journal of Business Economics and Management 12(1): 49-68.

Tvaronavičienė, M.; Grybaite, V.; Tunčikienè, Ž. 2013. Globalization drivers in developed and less developed countries: if consistent patterns can be traced, Journal of Security and Sustainability Issues 2(4): 5-11. http://dx.doi.org/10.9770/jssi.2013.2.4(1)

Tvaronavičiene, M.; Kalašinskaite, K. 2010. Whether globalization in form of FDI enhances national wealth: empirical evidence from Lithuania, Journal of Business Economics and Management 11(1): 5-19.

Tvaronavičiene, M.; Lankauskiene, T. 2013. The impact of production factors and economic structures on economic development, Verslas: teorija ir praktika - Business: Theory and Practice 14(1): 5-16. http://dx.doi.org/10.3846/btp.2013.01

United Nations database [online], [cited 01 July 2013]. Available from Internet: http://unstats.un.org/ unsd/snaama/dnlList.asp

Vitas, A. 2012. The economy structural changes analysis and evaluation in Baltic States: Summary of Doctoral Dissertation. 40 p.

Vosylius, E.; Rakutis, V.; Tvaronavičienè, M. 2013. Economic growth, sustainable development and energy security interrelation, Journal of Security and Sustainability Issues 2(3): 5-14. http://dx.doi.org/10.9770/jssi.2013.2.3(1)

Woodall, C. W.; Ince, P. J.; Skog, K. E.; Aquilar, F. X., et al. 2011. An overview of the forest products sector downturn in the United States, Forest Product Journal 61(8): 595-603.

Gitana DUDZEVIČıŪTĖ. Asssociate Professor, Dr. Works at the General Jonas Žemaitis Military Academy of Lithuania and Vilnius Gediminas Technical University. Research interests: economic growth, sustainable development, banking.

Alminas MAČIULIS. Chancellor of the Government of the Republic of Lithuania, Dr. Research interests: transport, communication sector of Lithuania, investments, innovations, economics and politics of the European Union.

Manuela TVARONAVIČIENĖ. Professor, Dr. Works at Vilnius Gediminas Technical University and the General Jonas Žemaitis Military Academy of Lithuania. Research interests: economic growth, sustainable development, innovations, investments, economic restructuring. 